Pelita Eksakta,

Vol.03, No.02, 2020 pp. xx-xx

10.24036/pelitaeksakta/vol3-iss2/122

www.pelitaeksakta.ppj.unp.ac.id

\title{
Guidance on Writing Proposals and Carrying Out Classroom Action Research (PTK) and Making PTK Reports in Article Form For High School Chemistry Teachers in Bukittinggi City
}

\author{
Alizar Ulianas ${ }^{\# 1}$, Minda Azhar ${ }^{1}$, Eka Yusmaita ${ }^{1}$, Miftahul Khair ${ }^{1}$, Yanti Fitria ${ }^{2}$, Hesty \\ Parbuntari $^{1}$, Watin Dehistora ${ }^{1}$, Yulia Mona Liza ${ }^{1}$ \\ ${ }^{1}$ Jurusan Kimia, Fakultas Matematika dan Ilmu Pengetahuan Alam \\ Universitas Negeri padang, Jl.Prof. Dr. Hamka Air Tawar. Padang, Sumatera Barat, Indonesia \\ ${ }_{2}^{2}$ Jurusan Pendidikan guru Sekolah Dasar, Fakultas Ilmu Pendidikan. \\ Universitas Negeri padang, Jl.Prof. Dr. Hamka Air Tawar. Padang, Sumatera Barat, Indonesia \\ *Corresponding: minda@ fmipa.unp.ac.id; Tel.: +6281267225154
}

Diterima 13 April 2020 Disetujui 13 Oktober 2020 Dipublikasikan 30 November 2020

\begin{abstract}
This study aims to serve the community in the framework of guidance in writing proposals and carrying out classroom action research (CAR) as well as making PTK reports in the form of articles for chemistry teachers so that they can be published in national or international journals. This research was conducted at SMAN 1 Kota Bukittinggi for 2 days with 13 chemistry teachers as participants. In the implementation of this guidance, 4 methods are carried out. First, the lecture method when delivering the material; second, the question and answer method; third, the implementation practice is accompanied by a team of experts; fourth, discussion to identify the success of the participants. Before and after the activity, participants were given a questionnaire regarding the participants 'needs for the material and participants' understanding of the material. In this activity participants can find out about problems in class and also how to search for PTK articles online, methods and techniques for writing PTK results articles, techniques for submitting PTK results articles to National journals, and using the Mendeley program to facilitate writing citations and bibliography on articles. The results of the participants' understanding before delivering the material and after delivering the material experienced a significant increase which was indicated by an increase in the number of participants who understood. Guidance on writing articles and preparing CAR provides motivation for teachers to make scientific papers in the form of articles until they can be published.
\end{abstract}

Keywords: Class action research, Article, Mendeley

\section{Pendahuluan}

Pendidikan merupakan proses pengembangan potensi yang dilakukan secara sadar dan terprogram untuk mempersiapkan diri menghadapi permasalahan yang ada. Kemajuan dibidang pendidikan sebenarnya bertujuan untuk meningkatkan kecerdasan dan kualitas sumber daya manusia. Untuk mewujudkan tujuan tersebut diperlukannya guru yang berkompetensi, karena guru merupakan pilar utama pendidikan [10]. Peran guru sangat penting dalam perkembangan dan kemajuan pendidikan. Proses pembelajaran akan berhasil jika seorang guru mampu menerapkan pendekatan, metode, model, dan media pembelajaran yang tepat [13]. Guru merupakan profesi yang tugas utamanya mendidik, mengajar, mengarahkan, membimbing, melatih, serta mengevaluasi dan menilai siswa [8]. Dalam mengembangkan profesionalismenya [7], seorang guru selain mengajar juga dituntut untuk melakukan pengembangan diri. Peraturan Menteri Pendidikan Nasional No 16 tahun 2007 mengenai Standar Kompetensi Guru menyatakan bahwa 
guru harus memiliki empat kompetensi utama yaitu kompetensi pedagogik, kompetensi kepribadian, kompetensi sosial, dan kompetensi professional [10]. Untuk mendukung hal tersebut pemerintah mengeluarkan beberapa kebijakan untuk membantu pengembangan kompetensi guru, seperti melalui kegiatan penelitian khususnya penelitian tindakan kelas (PTK), melaporkan hasil penelitian dalam bentuk karya tulis ilmiah, serta dapat mempublikasikannya ke dalam jurnal nasional [8]).

PTK merupakan bentuk penelitian yang dapat meningkatkan kualitas proses pembelajaran, dalam penelitian PTK ini guru tidak hanya bertindak sebagai peneliti, namun juga bertindak sebagai pelaksana proses pembelajaran. Sehingga, guru akan mengetahui secara lansung permasalahan yang terjadi serta dapat memacu tujuan yang hendak dicapai [8]. Hasil-hasil penelitian tindakan kelas yang dilakukan guru selanjutnya diaktualisasikan dalam bentuk laporan tertulis mengikuti kaidah-kaidah penulisan ilmiah dan hasilnya akan dapat berupa karya tulis ilmiah. Kemudian, guru akan mempublikasikan penelitian dalam bentuk artikel ilmiah yang terakreditasi baik tingkat lokal, nasional (ISSN), maupun terakreditasi internasional. Melalui publikasi ilmiah, guru telah dapat mendesiminasikan hasil riset mereka dan dapat menjadi referensi bagi guru atau peneliti lain dalam pengembangan keilmuan berbasis riset.

Hasil riset ini dituangkan dalam sebuah karya ilmiah yang dikenal dengan istilah artikel ilmiah. Artikel ilmiah adalah wadah untuk menulis suatu permaslahan yang faktual dan telah dibuktikan kebenarannya yang kemudian dimuat diberbagai media, seperti majalah, jurnal, bulletin, koran, dengan syarat penulisan mengikuti aturan penulisan dimana artikel tersebut akan diterbitkan. Penulisan artikel ini bertujuan untuk menyampaikan data faktual dari sebuah permasalahan guna memberikan informasi yang valid, mendidik, serta memberikan solusi terhadap permasalahan yang mungkin juga dialami pihak lain [5]. Artikel ilmiah ini didapatkan dari penelitian lansung, dan juga dari teori-teori yang kemudian dianalisis secara mendalam.

Dalam menulis karya ilmiah dibutuhkanlah kemampuan memahami serta menganalisis secara mendalam tentang topik permaslahan yang menjadi dasar penulisan sebuah karya. Hal ini diperlukan untuk pengembangan keprofesionalan dalam riset. Selain kemampuan memahami dan menganalisis, juga diperlukannya kemampuan mengumpulkan data, mengevaluasi, dan membuat topik yang diteliti menjadi lebih menarik serta berguna bagi setiap disiplin ilmu [4]. Oleh karena itu, perlunya pelatihan dan bimbingan untuk keprofesionalan guru dalam menulis dengan baik dan benar serta dengan cara yang mudah dan menyenangkan. Karena faktanya banyak peneliti yang mengalami kesulitan dalam menulis artikel, dan sebagian dari mereka mengikuti training untuk mengetahui bagaimana cara mempublikaiskan penelitian mereka dalam format penulisan yang benar [2].

Dalam penulisan artikel mengharuskan teknik penulisan baku dan sesuai dengan ketentuan yang ada, seperti sistematis, objektif, logis, menyeluruh, seksama, jelas, kebenaran teruji, dan penyajiannya sesuai dengan ketentuan penulisan baku yang disyaratkan oleh penerbit jurnal dimana artikel dikirim.

Ketika kita menulis artikel ini kita juga harus menuliskan secara lengkap referensi yang kita gunakan. Karena referensi ini sangat dibutuhkan untuk keakuratan karya ilmiah serta untuk menghindari perbuatan plagiarism [9]. Dalam penulisan artikel ini akan terasa rumit untuk menyusun daftar pustakanya dan akan membutuhkan waktu yang lama untuk mengetiknya. Oleh karena itu alangkah lebih baiknnya kita menggunakan aplikasi yang dapat mempermudah kita dalam penyusunan daftar pustaka tersebut. Salah satu aplikasi yang dapat digunakan adalah Mendeley.

Mendeley merupakan sebuah aplikasi yang dikhususkan untuk mengintegrasikan citation \& reference manager ke dalam sebuah jejaring sosial, dimana peneliti di berbagai belahan dunia dapat berkolaborasi dan melakukan sharing data penelitian [6]. Mendeley dapat diakses melalui aplikasi desktop, web, dan mobile dengan menyediakan full-text search terhadap seluruh paper dalam database dan berbagi dokumen pada database dengan pengguna lain serta sinkronisasi pustaka referensi dengan data yang tersimpan di server web Mendeley $[1,6]$. 
Dalam aplikasi Mendeley ini terdapat bermacam-macam style untuk penulisan referensi daftar pustaka. Kita dapat memilih style yang kita inginkan, ataupun mencocokkan dengan style yang diminta penerbit dimana karya kita akan diterbitkan. Dalam tulisan ini, penulis menggunakan American Political Science Association style. Mendeley yang telah diinstal, akan langsung terintegrasi dengan Microsoft word, sehingga penyusunan dafar pustaka akan diurut sesuai dengan metode yang dipilih. Setelah tulisan kita siap, langkah berikutnya persiapan untuk publikasi.

Berdasarkan analisis situasi guru-guru kimia SMA Kota Bukittinggi ada beberapa masalah yang dihadapi oleh guru-guru sebagai berikut: 1) Kurangnya pengetahuan tentang PTK dan bagaimana cara melakukakan pembuatan artikel; 2) Meskipun sebahagian guru telah mengetahui tentang permasalahan PTK maupun pembuatan artikel, tetapi mereka tidak mengetahui bagaimana metode pembuatan artikel yang mudah, baik dalam penulusuran literature, maupun dalam penulisan artikel itu sendiri sehingga hasil penelitian tersebut tidak dapat dipublikasikan pada jurnal, baik jurnal Nasional maupun jurnal Internasioanl. Akibatnya menyebabkan para guru tidak dapat memenuhi salah satu unsur pengembangan profesi. Untuk mengatasi permasalahan tersebut, perlu adanya bimbingan menulis proposal dan melaksanakan penelitian tindakan kelas (PTK) serta membuat laporan PTK dalam bentuk artikel bagi guru-guru kimia SMA Kota Bukittinggi agar artikel dapat dipublikasikan pada jurnal Nasioanl atau Internasional.

\section{Metode Penelitian}

Dalam memberikan keterampilan menulis artikel kepada para guru digunakan metode ceramah dan praktik. Metode ceramah digunakan untuk menyampaikan materi/teori yang berkaitan dengan penulisan artikel. Setelah peserta menerima penjelasan mengenai tata cara penulisan artikel yang baik dan benar, peserta diberikan kesempatan untuk mempraktikkannya dengan menulis artikel dari hasil penelitian tindakan kelas. Untuk mengidentifikasi keberhasilan peserta pelatihan dalam penulisan artikel digunakan metode diskusi.
Langkah-langkah kerja yang dilakukan dalam bimbingan ini adalah: 1) Memberi pembekalan kepada peserta tentang cara dan metode; (Teknik mengidentifikasi masalah pembelajaran di dalam kelas, Metode menyusun proposal PTK, Teknik melakukan PTK, Teknik menulis hasil laporan dan Teknik mengubah laporan hasil penelitian menjadi artikel yang bisa dipublikasi pada jurnal nasional), Peserta dibimbing untuk 2) menulis proposal PTK dari permasalahan yang telah diidentifikasi, 3) cara melakukan PTK berdasarkan proposal yang telah dibuat, 4) membuat laporan hasil PTK, 5) cara mengubah laporan PTK menjadi manuskrip yang dapat dipublikasikan pada jurnal Nasional, 6) cara mempublikasi artikel pada jurnal Nasional. Kegiatan ini dilakukan secara bertahap yang dimulai dari pembekalan guru tentang PTK oleh nara sumber. Kemudian para guru melakukan kegiatan secara mandiri untuk mengidentifikasi masalah pembelajaran di dalam kelas, cara membuat proposal, membuat laporan hasil penelitian.

Sebelum dilakukan bimbingan, terlebih dahulu dilakukan analisis tingkat keperluan peserta terhadap materi bimbingan dan sesudah bimbingan dilakukan pula analisis tingkat kepahaman peserta terhadap materi bimbingan yang telah disampaikan. Teknik pengambilan data berupa angket.

\section{Analisis Kepeluan Peserta terhadap Materi Sebelum Bimbingan}

Sebelum dilakukan kegiatan bimbingan penelitian tindakan kelas dan teknik menulis artikel, terlebih dahulu dilakukan analisis tentang perlu atau tidaknya materi yang disampaikan dalam kegiatan tersebut. Data anlisis ini dikumpulkan dengan menggunakan angket yang berisikan materi kegiatan sebanyak 6 pertanyaan dengan pilihan sangat perlu (SP), perlu (P), kurang perlu (KP) dan tidak perlu (TP). Keenam pertanyaan itu masing-masingnya adalah berisikan tentang: teknik pembuatan proposal PTK, teknik penulisan artikel hasil PTK, penggunaan internet untuk mencari sumber pembelajaran dalam bentuk artikel, pemilihan jurnal dan teknik submit artikel ke jurnal, penggunaan software mandeley untuk manajemen penulisan artikel dan cek plagiat 
menggunakan software Turnitin. Tingkat keperluan dihitung dari porsentase pilihan untuk setiap butir soal yang dihitung dengan persamaan berikut;

$$
\% \text { Keperluan }=(\mathrm{X} / \mathrm{Y}) \times 100 \%
$$

dimana $\mathrm{X}$ adalah peserta sedangkan $\mathrm{Y}$ adalah jumlah peserta yang memilih pilihan tertentu.

\section{Analisis Tingkat Kepahaman Peserta Setelah Bimbingan}

Tingkat kepahaman peserta bimbingan terhadap materi kegiatan diukur dengan menggunakan angket yang berisikan 21 pertanyaan tentang materi yang disampaikan. Pertanyaan ini dikelompokan menjadi; 3 aspek, yaitu; 1) aspek kepahaman tentang PTK, 2) aspek kepahaman artikel dan publikasi artikel pada jurnal dan 3) aspek kepahaman tentang sumber belajar online dan plagiat. Setiap pertanyaan berisi empat pilihan, yaitu; Sangat tidak paham (STP), tidak paham (TP), paham (P) dan sangat paham (SP). Sedangkan porsentase tingkat kepahaman peserta ditentukan dengan persamaan berikut:

$\%$ Kepahaman $=(B / A) \times 100 \%$

dimana A adalah peserta sedangkan B adalah jumlah peserta yang memilih pilihan tertentu.

\section{Pembahasan}

Melalui kegiatan bimbingan ini peserta telah dapat mengidentifikasi masalah dalam proses pembelajaran di kelas serta mampu menganalisis penyebab utama dari munculnya permasalahan tersebut. Kemudian peserta telah dapat menghasilkan judul proposal PTK sebanyak 16 judul dari 20 orang peserta yang siap utnuk dijadikan proposal PTK. Pelaksanaan kegiatan dapat ditunjukkan pada gambar 1.

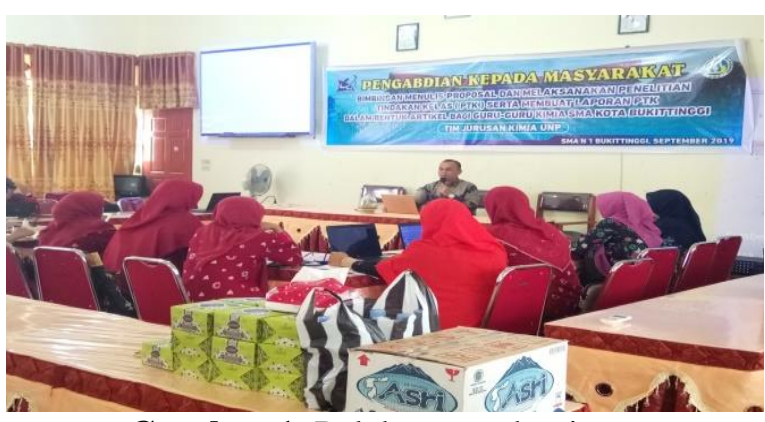

Gambar 1. Pelaksanaan kegiatan

\section{Analisis Kepeluan Peserta terhadap Materi Bimbingan}

Minat peserta pelatihan penulisan artikel sangatlah tinggi, ditandai dengan antusisme peserta mengikuti pelatihan selama dua hari, dari pagi sampai sore. Hal ini juga dibuktikan dengan angket analisis keperluan peserta terhadap materi bimbingan tentang teknik pembuatan proposal PTK dan keknik penulisan artikel hasil PTK dengan persentase $100 \%$ peserta memilih sangat perlu. Hal ini sangat dibutuhkan oleh guru untuk memajukan pendidikan nasional dan menyiapkan sumber daya manusia yang berkualitas serta untuk memenuhi pengembangan keprofesian guru salah satunya dengan cara publikasi ilmiah [11]. Penggunaan internet untuk mencari sumber pembelajaran dalam bentuk artikel dengan persentase $92 \%$ sangat perlu dan $8 \%$ perlu. Dalam penulisan artikel ini membutuhkan sumber yang akurat dan tentunya harus memenuhi standar dimana artikel akan diterbitkan sehingg diperlukan teknik untuk pembuatan dan penyususnan referensi otomatis agar lebih dimudahkan dalam penulisan. Mandeley merupakan salah satu solusi untuk mengatasi hal tersebut, dimana mandeley telah terintegrasi ke word dan proses sitasi bisa dilakukan dengan mudah. Peserta bimbingan ini menyatakan bahwa pemilihan jurnal dan teknik submit artikel ke jurnal dan penggunaan software manajemen referensi (software mandeley) mengatakan sangat perlu dengan persentase $77 \%$ dan $23 \%$ perlu. Kemudian, setelah artikel selesai, dan untuk menguji keoriginalan data yang kita buat diartikel dibutuhkannya cel plagiat menggunakan software Turnitin/online dengan persentase $62 \%$ sangat perlu dan $38 \%$ perlu. 
Dalam hal ini peserta menyadari pentingnya PTK untuk meningkatkan ketuntasan belajar dan prestadi afektif siswa [12].

Setelah memberikan angket keperluan peserta terhadap materi bimbingan ini, kemudian diberikan angket mengenai pemahaman peserta terhadap materi. Hasil analisis angket sebelum materi menunjukkan bahwa kepahaman peserta tentang PTK menunjukkan $2 \%$ peserta sangat tidak paham, $32 \%$ peserta memilih tidak paham dan $61 \%$ peserta memilih paham dan $5 \%$ peserta memilih sangat paham. Pemahaman ini perlu dalam merancang dan melakukan PTK [5]. Sedangkan aspek kepahaman peserta tentang artikel dan publikasi artikel pada jurnal juga menunjukkan paham yang ditunjukkan $2 \%$ peserta yang menyatakan sangat tidak paham, $62 \%$ tidak paham, 33\% paham, dan 3\% sangat paham. Kepahaman ini diperlukan untuk menunjukkan kemampuan peserta untuk mengetahui dan memilih jurnal untuk mempublikasikan artikel yang telah ditulis [3]. Selain itu dari aspek kepahaman peserta tentang mencari dan mendownload sumber belajar online dan kepahaman tentang plagiat juga menunjukkann $10 \%$ sangat tidak paham, 58\% tidak paham, 31\% paham $2 \%$ sangat paham. Tingkat kepahaman ini menunjukkan bahawa peserta mengetahui betapa banyaknya sumber belajar online dan mengerti/memahami tentang keburukan dari plagiat.

Hasil analisis setelah materi menunjukkan bahwa kepahaman peserta tentang PTK menunjukkan $0 \%$ peserta sangat tidak paham, $1 \%$ peserta memilih tidak paham dan $52 \%$ peserta memilih paham dan $47 \%$ peserta memilih sangat paham. Sedangkan aspek kepahaman peserta tentang artikel dan publikasi artikel pada jurnal juga menunjukkan paham yang ditunjukkan 0\% peserta yang menyatakan sangat tidak paham, $0 \%$ tidak paham, 68\% paham, dan 32\% sangat paham. Selain itu dari aspek kepahaman peserta tentang mencari dan mendownload sumber belajar online dan kepahaman tentang plagiat juga menunjukkann $0 \%$ sangat tidak paham, $17 \%$ tidak paham, $65 \%$ paham $17 \%$ sangat paham.

Dari survei tersebut pemahaman sebelum penyampain bimbingan materi dengan setelah penyampaian materi mengalami kenaikan yang siknifikan. Dari sebelum penyampaian materi persentase (\%) sangat tidak paham dan tidak paham mendominasi, sedangkan setelah penyampaian materi diperoleh $0 \%$ peserta sangat tidak paham dan pserta yang paham dan sangat paham lebih mendominasi.

Jadi, secara umum peserta dapat memahami penyampaian materi dalam bimbingan menulis proposal dan melaksanakan penelitian tindakan kelas (PTK) serta membuat laporan PTK dalam bentuk artikel bagi guru-guru kimia SMA Kota Bukittinggi.

\section{Kesimpulan}

Penelitian Tindakan Kelasa (PTK) adalah hal yang tidak bisa dipisahkan oleh guru dari proses pembelajaran di kelas. PTK ini penting dilakukan untuk mengetahui permasalahan yang dihadapi oleh siswa guna meningkatkan mutu pendidikan serta mengembangkan profesionalisme guru, sesuai dengan SK Menpan No. 84/1993 tanggal 24 Desember 1993 yang disempurnakan menjadi Permenneg PAN dan RB no. 16 tahun 2009 tentang jabatan fungsional dan pengembangan profesi guru. Kegiatan ini telah dilakukan kepada guru-guru kimia SMA Kota Bukittinggi. Dalam kegiatan ini peserta dapat mengetahui mengenai permasalahn dikelas dan juga cara penelusuran artikel PTK secara online, metode dan Teknik penulisan artikel hasil PTK, teknik submit artikel hasil PTK kepada jurnal Nasional, serta penggunaan program Mendeley untuk mempermudah penulisan citasi dan daftar pustaka pada artikel.

\section{Ucapan Terima Kasih}

Terimakasih kepada Kementrian Riset Teknologi dan Pendidikan Tinggi yang telah membiayai kegiatan ini melalui Dana DIPA Universitas Negeri Padang Tahun Anggaran 2019. Terimkasih kepada tim dari jurusan kimia, FMIPA Universitas Negeri Padang. Dan juga terimakasih kepada guru-guru kimia SMA kota Bukittinggi. 


\section{Pustaka}

[1] Agustiana, I Gusti Ayu Tri, I Nyoman Tika, and I Made Citra Wibawa., 2018, Pelatihan Membuat Daftar Isi Dan Daftar Pustaka Dengan Sekali Klik Berbantuan Mendeley Bagi Para Dosen PTS Dalam Menyusun Artikel Dan Laporan Penelitian Se-Kabupaten Buleleng, International Journal of Community Service Learning, Vol. 2, No. 2, 116-23.

[2] Bruce., 2011, 2013. “済無No Title No Title. Journal of Chemical Information and Modeling, Vol. 53 No. 9, 1689-99.

[3] Farid, Muhammad., 2017, Menulis Artikel Ilmiah: Menemukan Ide Hingga Publikasi.Jurnal Penulisan Artikel ilmiah, Vol. 1, No. 1, 1-9.

[4] Gilinsky, Armand, Sharon L. Forbes, and Marlene M. Reed., 2016, Writing Cases to Advance Wine Business Research and Pedagogy: A Business Article By. Wine Economics and Policy, Vol. 5, No. 1, 60-67.

[5] Gunawan, Imam, Teguh Triwiyanto, and Desi Eri Kusumaningrum., 2018, Pendampingan Penulisan Artikel Ilmiah Bagi Para Guru Sekolah Menengah Pertama, Abdimas Pedagogi: Jurnal Ilmiah Pengabdian kepada Masyarakat, Vol. 1 No. 2, 128-35.

[6] Handayani, Indri, Erick Febriyanto, and Teguh Arya Yudanto., 2019, Pemanfaatan Indeksasi Mendeley Sebagai Media Pengenalan Jurnal STT Yuppentek, Technomedia Journal, Vol .3, No.2, 235-45.

[7] Hikmawati, Hikmawati, Joni Rokhmat, Kosim Kosim, and Sutrio Sutrio., 2019, Pendampingan Penyusunan Proposal PTK Untuk Meningkatkan Profesionalisme Guru Di SMA Negeri 2 Gerung, Jurnal Pengabdian Magister Pendidikan IPA, Vol.1, No.2.

[8] Hunaepi et al., 2016, Pelatihan Penelitian Tindakan Kelas (Ptk) Dan Teknik Penulisan Karya Ilmiah Bagi Guru Di Mts. Nw Mertaknao, Lumbung
Inovasi, Vol. 1, No. 1: 38-40.

[9] Pekanbaru, Guru-guru SMA Negeri et al., 2019, Pelatihan, Pembimbingan Ptk Dan Publikasi Ilmiah, Vol. 3, No. 1, 46-51.

[10] Pramusinto, Hengky, Indri Murniawaty, Hana Netti Purasani, and Nanik Suryani., 2019, Pengembangan Kompetensi Menulis Artikel Hasil PTK Guru Ekonomi SMA Kabupaten Semarang, Jurnal PkM Pengabdian kepada Masyarakat, Vol. 2, No. 1, 14.

[11] Redhana, I Wayan., 2017, Pelatihan Penulisan Artikel Ilmiah Bagi GuruGuru Kimia Di Kabupaten Buleleng, Jurnal Widya Laksana, Vol. 3, No. 2, 20.

[12] Rizki, Rohazmy, Asep Wahyu Nugraha, and Erlina Erlina., 2019, Efektivitas Model Pembelajaran Learning Cycle Dalam Upaya Meningkatkan Hasil Belajar Kimia Siswa Pada Pokok Bahasan Kesetimbangan Kimia Melalui Pendekatan Penelitian Tindakan Kelas, Talenta Conference Series: Science and Technology (ST), Vol. 2, No. 1, 216219.

[13] Wedekaningsih, Arfika, Henny Dewi Koeswati, and Sri Giarti., 2019, Penerapan Model Discovery Learning Untuk Meningkatkan Keterampilan Berpikir Kritis Dan Hasil Belajar Matematika, Jurnal Basicedu, Vol. 3, No. 1, 21-26.

[14]Dwidjoseputro, D., 1980, Pengantar Fisiologi Tumbuhan, Gramedia, Jakarta. Engelstad, O.P., 1997, Teknologi dan Penggunaan Pupuk, Diterjemahkan oleh DH. Goenadi, Gadjah Mada University Press, Yogyakarta.

[15] Parman, S., 2007, Pengaruh Pemberian Pupuk Organik Cair terhadap Pertumbuhan dan Produksi Kentang (Solanum tuberosum L.), Buletin Anatomi dan Fisiologi, Vol. 15, No. 2, 2131. 